\title{
IMPACT OF ALTERED EXPRESSION OF MATRIX METALLOPROTEINASES (MMPS) ON THE DEVELOPMENT AND SEVERITY OF DIABETIC RETINOPATHY.
}

Lakshmi K Mandal1, Subhojit Choudhuri², Suman K Paine³, Aditi Sen4, Gautam Bhaduri5, Basudev Bhattacharya ${ }^{6}$.

1. Professor, Department Of Ophthalmology, Regional Institute Of Ophthalmology Medical College, Kolkata

2. PhD Scholar, Department Of Ophthalmology, PGMER.

3. PhD scholar, Department Of Ophthalmology, PGMER.

4. PhD scholar, Department Of Ophthalmology, PGMER.

5. Director of Medical, Regional Institute Of Ophthalmology Medical College, Kolkata

6. Director Of Medical Education, Department of Ophthalmology, Government of Tripura.

\section{CORRESPONDING AUTHOR:}

Lakshmi K Mandal.

Regional Institute of Ophthalmology,

Medical College, Kolkata.

E-mail:lakshmi-mandal26@gmail.com

INTRODUCTION: The primary cause of visual loss in the country like India are cataract, glaucoma, malnutrition, age related macular degeneration and diabetic retinopathy (DR) ${ }^{1}$.DR is the most common microvascular complication of both type 1 and type 2 diabetes mellitus (DM) and is the most frequent single cause of newly reported cases of blindness among the adults in the age group of 20 - 75 years ${ }^{2}$. Visual loss due to diabetes either develops from increased permeability of retinal vessels (diabetic macular edema) or by proliferation of new retinal vessels ${ }^{2}$.

Several angiogenic factors such as VEGF, PDGF, and TNF- $\alpha$ exhibit their potential signature on the development and progression of DR which ultimately results in the neovascularization process $^{3}$. So far only VEGF has been largely implicated in deposition of extracellular matrix (an essential step in the new vessel formation) and play the crucial role by stimulating angiogenesis and inhibiting the endothelial function in retinal ischemic conditions. ${ }^{3}$ Among the various processes that regulate angiogenesis, the generation of proteolytic activity is thought to be pivotal in the regulation of cell migration and capillary tube formation. Pericellular proteolysis and capillary-like tubule formation by endothelial cells are achieved by cell-bound urokinase-type plasminogen activator ( $\mathrm{u}-\mathrm{PA}$ ) and plasmin as well as matrix metalloproteinases (MMPs) ${ }^{4}$. Membrane-type MMPs (MT - MMPs) have been suggested to play a key role in angiogenesis, in addition to the gelatinases MMP-2 and -9 5. As a family of zinc-binding, calcium-dependent endopeptidases, matrix metalloproteinases (MMPs) expressed in various tissues and cells are responsible for the dissolution of extracellular matrix 6.MMPs play a major role in normal development, reproduction, and tissue remodeling 7 . In addition, these molecules are involved in a number of pathogenic processes including cancer, arthritis and other angiogenic disorder. ${ }^{8}$ Recently there have been a number of important discoveries on the role of MMPs in the eye. MMP activity is modulated through interaction with the MMP inhibitors, i.e., tissue inhibitors of metalloproteinases (TIMPs). ${ }^{7}$ MMP activities are regulated by transcriptional control, by proenzyme activation. MMPs are 
involved in the degradation of a variety of extracellular matrix (ECM) molecules, and ECM homeostasis.

Considering the finding that DR is initially caused by breakdown of inner blood-retinal barrier and later by fibrovascular proliferation; it is possible that MMP expression might change in the development and progression of DR and the extracellular matrix degradation would be also accompanied accordingly. To understand the pathogenic mechanism of the multifactorial disease like DR, we investigate the role of gelatinized MMPs from clinical isolates.

\section{METHODOLOGY: SELECTION OF PATIENTS:}

INCLUSION CRITERIA: The study included 373 subjects suffering from DR ( $\mathrm{n}=253,60,60$ subjects suffering from proliferative DR, severe non proliferative DR and mild non proliferative DR, respectively) as a long term complication of type $2 \mathrm{DM}$ and 240 age, sex, nutrition and glycemic level matched type 2 diabetic controls (duration of diabetes $17 \pm$ 5years) without retinopathy and 100 non diabetic healthy control. DR cases were recruited from the retina clinic of the Regional Institute of Ophthalmology, Kolkata, India and the controls were recruited at the diabetic clinic of the Institute of Post-graduate Medical Education and Research, Kolkata; India. All the study subjects belonged to the same community (same ethnic group) -Bengali Hindu, living in geographical proximity and are assumed to be pan-mixing. Institutional ethical clearance and written informed consent from each subject was obtained according to the Declaration of Helsinki.

Diagnosis of DM was made according to WHO criteria (WHO, 2006). Diagnosis of PDR was done by well qualified retina specialist through dilated fundus examination with slit lamp biomicroscopy by +90D and 3 mirror lens, seven field digital fundus photography with fluorescence angiography. Grading or scale of severity of retinopathy was based on modified early treatment diabetic retinopathy study (ETDRS). Among those the PDR $(n=48)$ subject who were in the proliferative stage; had undergone pars plana vitrectomy and undiluted vitreous were collected from these patients for selective protein study.

30 subjects who underwent vitrectomy for idiopathic macular hole were included as control for vitreous study. This disorder is caused by vitreo-macular traction occurring prior to posterior vitreous detachment and there are no signs of ischemia, proliferation or inflammation.

EXCLUSION CRITERIA: People with coronary artery diseases (CAD), hypertension, peripheral vascular diseases, CAD, history of any thrombotic event, acute infection, patients having any other ocular disorder like glaucoma, branch retinal venous occlusion and Eales' disease were excluded from the study. In order to exclude overt diabetic nephropathy patients, subjects with micro albumin-creatinine ratio $>30 \mathrm{mg} / \mathrm{gm}$ and urinary micro albumin level $>300 \mathrm{mg} /$ day were excluded from the study (Alvin, 2005).

SAMPLE COLLECTION AND PREPARATION FOR ANALYSIS: $10 \mathrm{ml}$ of whole blood from DR patients and controls were collected by venipuncture from peripheral veins. $7 \mathrm{ml}$ of blood was taken in a EDTA containing tube for PBMC layer separation. Rest of $3 \mathrm{ml}$ was collected in clot vial and allowed to clot. After clot retraction, serum was separated by centrifugation at $3,000 \mathrm{~g}$ at $4^{\circ} \mathrm{C}$ for 20 minutes stored at $-80^{\circ} \mathrm{C}$ until further use. 
Vitreous samples were collected from the study subjects and control patients who underwent three-port pars plana vitrectomy. After the construction of the ports, vitreous cutter was introduced in mid vitreous, before turning the infusion fluid $200 \mu \mathrm{l}$ of undiluted vitreous gel was excised and aspirated into the hand held sterile syringe attached to the suction port of the vitrectomy probe, using manual suction with high cutting rate. The vitreous biopsy samples thus obtained were immediately put in ice, centrifuged at $10,000 \mathrm{~g}$ for 15 minutes at $4^{\circ} \mathrm{C}$. After centrifugation supernatants were divided in two equal aliquot and stored at $-20^{\circ} \mathrm{C}$ for immediate use and at $-80^{\circ} \mathrm{C}$ for future use. Simultaneously venous blood was collected from those patients at the time of vitrectomy and processed as stated earlier.

The Demographic and clinical characterization of the study subjects were presented in table 1(DR and DC) and table2 (DC and HC) There was no significant difference in age, sex, blood pressure, and nutritional status between the study groups. The glycemic control were matched among the diabetic subjects.

TOTAL PROTEIN ESTIMATION FROM CLINICAL ISOLATES: Total protein from clinical isolates (serum and vitreous fluid) as well as cell culture supernatant and cell lysates were estimated by Bicinchoninic acid (BCA) assay (Smith et al., 1987) ${ }^{9}$ as per requirement. Protein (mg/ml) levels were estimated by using BCA reagent (Sigma) containing 4\% copper sulphate (CuSO4).

Total concentration of gelatinized MMPs i.e. MMP2 and MMP9 in vitreous and serum of study subjects were measured using a commercial ELISA kit (R\&D Systems).

\section{CONCENTRATION OF GELATINIZED MMPS (MMP2 AND MMP9) IN VITREOUS FLUID OF PDR SUBJECTS AND THE SERUM LEVEL OF THE SAME CYTOKINE IN DIFFERENT STAGES OF DR.}

Gelatinized vitreous MMPs concentration (MMP2 and MMP9) was found significantly higher than that of controls [260.18 $\pm 97.69 \mathrm{ng} / \mathrm{ml}$ (PDR) vs. $86.79 \pm 39.73 \mathrm{ng} / \mathrm{ml}$ (Control); $<<0.0001$ for MMP2 and $52.34 \pm 26.14 \mathrm{ng} / \mathrm{ml}(\mathrm{PDR})$ vs. $26.21 \pm 8.87 \mathrm{ng} / \mathrm{ml}$ (Control); $\mathrm{p}=0.0002$ for MMP9.Table3

The serum level of MMP2 and MMP9 were found to be significantly elevated in mild NPDR(MMP2: $167.36 \pm 42.4 \mathrm{ng} / \mathrm{ml}, \mathrm{MMP} 9: 732.62 \pm 256.51$ ) subject compared to control (DC) [MMP2: $99.44 \pm$ $27.58 \mathrm{pg} / \mathrm{ml}$ MMP9: $611.11 \pm 60.26$ ]; $\mathrm{p}<0.0001$ for MMP2 and $\mathrm{p}<0.0001$ for MMP9 .Further the concentration of MMP2 and MMP9 significantly upregulated in severe NPDR subject(MMP2:188.13 $\pm 44.29 \mathrm{ng} / \mathrm{ml}$.MMP9: $902.25 \pm 114.28$ ) compared to mild NPDR ; $<0.0118$ for MMP2 and $\mathrm{p}<0.0001$ for MMP9.The MMP2 level insignificantly elevated in PDR subject (198.85 $\pm 48.47 \mathrm{ng} / \mathrm{ml}$ ) compared to severe NPDR $\mathrm{p}=0.3447$ and MMP9 level reach its most activation sate on PDR subject $(1265.4 \pm 156.04 \mathrm{ng} / \mathrm{ml})$ vs. severe NPDR; $\mathrm{p}<0.0001]$. Further it was also noted that the serum MMP2 and MMP9 concentration significantly elevated in DC compared to Healthy control (Table 4).

DISCUSSION: PDR is a common complication of type2 (and type1) DM, characterised by periretinal neo-vascularization and development of epiretinal fibrovascular tissue ${ }^{10,11}$.Early features of DR include selective loss of intramural pericytes from retinal capillaries which leads to damage of the inner blood-retinal barrier (Aiello et al.,1995. This process is followed by neo-vascularization, involving the production of angiogenic factors as well as synthesis of extracellular matrix (ECM) necessary for anchorage of migrating endothelium and other cells such as retinal pigment 
epithelium (RPE), glial cells, and fibroblasts ${ }^{11}$. Degradation of ECM proteins is exerted by MMPs, a family of zinc binding, calcium dependent enzymes ${ }^{12}$. Our present study demonstrated that MMP2 and MMP9 markedly upregulated in the vitreous fluid in PDR subjects compared to control. Further this MMPs particularly MMP9 gradually elevated at regular manner in serum level during the severity of DR which may act as the marker for adverse prognosis of this microvascular complication of type2 DM. Serum MMP2 activated at MNPDR and SNPDR subjects and may established its pathogenic potentiality for the initiation of this retinal complication among the prolonged hyperglycemic subjects. Activation of MMPs both in vitreous and serum may play a crucial role in connective tissue remodelling and in the degradation of basement membrane and surrounding extracellular matrix during processes of angiogenesis. Extracellular proteinases (i.e., MMPs and urokinase plasminogen activator) may play an important and rate-limiting role in the process of neovascularization ${ }^{13}$ Expression of these proteinases is required for vascular endothelial cells to "break-through" their surrounding basement membrane and migrate through interstitial tissue toward the angiogenic stimulus ${ }^{14}$. Many angiogenic factors including VEGF, bFGF, TNF- $\alpha$ selectively stimulate the expression of various MMPs (MMP 1 to 3 and 9) in vascular endothelial cells 15. Agents that are MMPs enzyme inhibitors (batimastat, marimastat) and agents that alter vascular endothelial cells MMPs expression currently are being evaluated as angiostaticagents ${ }^{16}$. It also appears that the MMP system may be involved in regulating angiogenesis in a much more complex manner (Joseph etal., 2008).In addition, MMPs may be responsible for the generation of natural angiostatic substances such as angiostatin, which inhibits vascular endothelial cell proliferation and is the proteolytic product of plasminogen ${ }^{16}$. A recent study adds additional complexity to the role of MMPs in angiogenesis (Joseph etal.,2008). Previous studies hypothesized that that PEX, a proteolytic fragment of MMP-2 containing a hemopexin-like domain, inhibits the functional association of MMP-2 with an integrin receptor (av/33) on the surface of vascular endothelial cells ${ }^{17}$. PEX binding effectively blocks the expression of collagenolytic activity on vascular endothelial cells and is thereby angiostatic 18 . PEX progressively accumulates in the retina during retinal vasculogenesis, suggesting that it may play a normal role in the regulation of blood vessel formation (Brooks et al., 1998; Rupp et al.,2008 Alteration pattern also seen in the vitreous fluid where MMP2, and 9 are significantly elevated in the vitreous fluid of PDR subjects. Previously, retinal pigment epithelial(RPE) cells in culture have been shown to secrete both MMPs and TIMPs 19.

It is therefore suggested that systematic continuous activation of gelatinized MMPs in hyperglycemic subjects may exert its crucial role in connective tissue remodeling, degradation of basement membrane and surrounding extra cellular matrix during the process of progression of diabetic retinopathy leading to angiogenesis and fibro cellular proliferation.

\section{REFERENCES:}

1.GIUSTI C, GARGIULO P. Advances in biochemical mechanisms of diabetic retinopathy. Eur Rev Med Pharmacol Sci. 2007; 11: 155-163

2.Luk RM. Open Your Eyes. Health Dialogue. 2006; 44:1

3.Khan ZA and Chakraboarti S. Growth Factors in Proliferative Diabetic Retinopathy. Experimental Diabetes Research.2003;4:287-301. 
4.Brown D, Hamdi H, Bahri S, Kenney MC. Characterization of an endogenous metalloproteinase in human vitreous. Curr Eye Res 1994; 13:639-47.

5.Hernandez-Barrantes S, Toth M, Bernardo MM, et al. Binding of active (57 kDa) membrane type 1-matrix metalloproteinase (MT1-MMP) to tissue inhibitor of metalloproteinase(TIMP)-2 regulates MT1-MMP processing and Pro-MMP-2 activation. J Biol Chem. 2000; 275:12080-12089.

6.Salzmann J, Limb GA, Khaw PT, Gregor ZJ, Webster L, Chignell AH, Charteris DG.Matrix metalloproteinases and their natural inhibitors in fibrovascular membranes of proliferative diabetic retinopathy. Br J Ophthalmol. 2000;84(10):1091-6

7.Jobim FC, Xavier Nl, Uchoa DM, Cruz DB, Saciloto M, Chemello N and Schwartsmann G. Prevalence of vascular-endothelial growth factor, matrix metalloproteinases and tissue inhibitors of metalloproteinases in primary breast cancer.

8.Braz J Med Biol Res. 2009; 42(10) :979.

9.Smith PK, Krohn RI, Hermanson GT, Mallia AK, Gartner FH, Provenzano MD, Fujimoto EK, Goeke NM, Olson BJ, Klenk DC.Measurement of protein using bicinchoninic acid.Anal Biochem. 1985;150(1):76-85. Erratum in: Anal Biochem 1987 May 15; 163(1):279.

10. Aiello L, Northrup J, Keyt B, et al. Hypoxic regulation of vascularendothelial growth factor in retinal cells. Arch Ophthalmol. 1995; 113:1538-1544.

11. El-Asar M A Abu, Al-Mezaine H S Ola MS: Pathophysiology and management of diabetic retinopathy. Expert Rev.Opthalmol2009; 4(6),627-47

12. Gomez DE, Alonso DF, Yoshiji H, Thorgeirsson UP. Tissue inhibitors of metalloproteinases: structure, regulation and biological functions. Eur J Cell Biol.1997;74: 111.

13. Konjevic G and Stankovic S.Matrix metalloproteinases in the process of invasion and metastasis of breast cancer. Arch Oncol 2006;14(3-4):136-40.

14. Nerenberg P.S., Salsas-Escat R and M. Stult C.M.Collagen - A Necessary Accomplice in the Metastatic Process.Cancer Genomics \& Proteiomix.2007; 4:319-328.

15. Folkman J. Angiogenesis. Annu Rev Med. 2006; 57:1-18.

16. Krüger A, Soeltl R, Sopov I, Kopitz C, Arlt M, Magdolen V, Harbeck N, GänsbacherB, Schmitt Joseph D. Raffetto JD and Khalil RA. Matrix Metalloproteinases and their Inhibitors in Vascular Remodeling and Vascular Disease. Biochem Pharmacol. 2008; 15; 75(2):346359.

17. Rupp PA, Visconti RP, Czirók A, Cheresh DA, Little CD.Matrix metalloproteinase 2- integrin alpha(v)beta3 binding is required for mesenchymal cell invasive activity but not epithelial locomotion: a computational time-lapse study.Mol Biol Cell. 2008 Dec; 19(12):5529-40.

18. Brooks PC, Silletti S, von Schalscha TL, Friedlander M, Cheresh DA.Disruption of angiogenesis by PEX, a non-catalytic metalloproteinase fragment with integrin binding activity. Cell. 1998 6; 92(3):391-400.

19. Eichler W, Friedrichs U, Thies A, Tratz C, Wiedemann P .Modulation of matrix metalloproteinase and TIMP-1 expression by cytokines in human RPE cells. Invest Ophthalmol Vis Sci. 2002 Aug; 43(8):2767-73. 
Table1. Clinical characteristics, nutritional and glycemic status among DR and DC

\begin{tabular}{|c|c|c|c|}
\hline Parameter & DR & DC & p-Value \\
\hline Age & $53 \pm 16$ & $54 \pm 12$ & 0.4 \\
\hline \multicolumn{4}{|l|}{ Sex } \\
\hline Male & $\begin{array}{l}203 \\
(54.42 \%)\end{array}$ & $128(53.33 \%)$ & 0.8 \\
\hline Female & $\begin{array}{l}170 \\
(45.58 \%)\end{array}$ & $112(46.67 \%)$ & \\
\hline $\begin{array}{l}\mathrm{HBA}_{\mathrm{I}} \mathrm{C}(\%) \\
\text { Urinary micro albumin } \\
\text { mg/day) } \\
\text { Urinary micro albumin } \\
\text { creatinine ratio (mg/gm) }\end{array}$ & $\begin{array}{l}7.8 \pm 1.2 \\
18.92 \pm 5.8 \\
18.23 \pm 5.19\end{array}$ & $\begin{array}{l}7.6 \pm 1.3 \\
18.1 \pm 6.08 \\
17.54 \pm 5.64\end{array}$ & $\begin{array}{l}0.51 \\
0.0942 \\
0.121\end{array}$ \\
\hline $\begin{array}{l}\text { Serum total protein } \\
(\mathrm{gm} / \mathrm{dl}))\end{array}$ & $7.18 \pm 1.02$ & $7.1 \pm 0.88$ & 0.3182 \\
\hline $\begin{array}{l}\text { Duration of diabetes } \\
\text { (years) }\end{array}$ & $18 \pm 6$ & $17 \pm 7$ & 0.0599 \\
\hline $\begin{array}{l}\text { Blood Systolic } \\
\text { Pressure }\end{array}$ & $132 \pm 9$ & $131 \pm 8$ & 0.1616 \\
\hline (mmHg) Diastolic & $83 \pm 6$ & $82 \pm 7$ & 0.0597 \\
\hline
\end{tabular}

Table2. Clinical characteristics, nutritional and glycemic status among DC and HC

\begin{tabular}{|c|c|c|c|}
\hline Parameter & $\mathrm{HC}$ & DC & p-Value \\
\hline Age & $52 \pm 13$ & $54 \pm 12$ & 0.21 \\
\hline $\begin{array}{l}\text { Sex } \\
\text { Male } \\
\text { Female }\end{array}$ & $\begin{array}{l}55(55 \%) \\
45(45 \%)\end{array}$ & $\begin{array}{l}128(53.33 \%) \\
112(46.67 \%)\end{array}$ & 0.82 \\
\hline $\begin{array}{l}\mathrm{HBA}_{\mathrm{I}} \mathrm{C}(\%) \\
\text { Urinary micro } \\
\text { albumin ( } \mathrm{mg} / \text { day) } \\
\text { Urinary micro } \\
\text { albumin creatinine } \\
\text { ratio }(\mathrm{mg} / \mathrm{gm})\end{array}$ & -------------- & $\begin{array}{l}18.1 \pm 6.08 \\
17.54 \pm 5.64\end{array}$ & -------------- \\
\hline $\begin{array}{l}\text { Serum total protein } \\
(\mathrm{gm} / \mathrm{dl}))\end{array}$ & $7.28 \pm 1.3$ & $7.1 \pm 0.88$ & 0.1395 \\
\hline $\begin{array}{ll}\text { Duration } & \text { of } \\
\text { diabetes (years) }\end{array}$ & 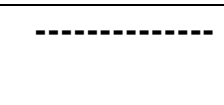 & $17 \pm 7$ & 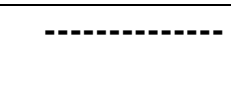 \\
\hline
\end{tabular}




\section{ORGINAL ARTICLE}

\begin{tabular}{|l|c|c|c|}
\hline & & & \\
\hline $\begin{array}{l}\text { Blood Systolic } \\
\text { Pressure }\end{array}$ & $\mathbf{1 3 0} \pm \mathbf{9}$ & $\mathbf{1 3 1} \pm \mathbf{8}$ & $\mathbf{0 . 3 1 2 5}$ \\
\hline (mmHg) Diastolic & $\mathbf{8 1} \pm \mathbf{8}$ & $\mathbf{8 2} \pm \mathbf{7}$ & $\mathbf{0 . 2 5 1}$ \\
\hline
\end{tabular}

Values are represented in mean \pm SD. p-value Significant at (0.05) level.

Table 3: Concentration of gelatinized MMPs (MMP2 and MMP9) in vitreous fluid of PDR subjects compare to control

\begin{tabular}{|l|l|l|}
\hline & MMP2 & MMP9 \\
\hline PDR & $260.18 \pm 97.69 \mathrm{ng} / \mathrm{ml}$ & $52.34 \pm 26.14 \mathrm{ng} / \mathrm{ml}$ \\
\hline Control & $86.79 \pm 39.73 \mathrm{ng} / \mathrm{ml}$ & $26.21 \pm 8.87 \mathrm{ng} / \mathrm{ml}$ \\
\hline P-VALUE & $\mathrm{p}<0.0001$ & $\mathrm{p}=0.0002$ \\
\hline
\end{tabular}

TABLE 4: Concentration of gelatinized MMPs (MMP2 and MMP9) in serum among different degrees of DR subjects

\begin{tabular}{|l|l|l|l|l|}
\hline & MMP2 & P-VALUE & MMP9 & P=VALUE \\
\hline HC & $82.42 \pm 59.73 \mathrm{ng} / \mathrm{ml}$ & $<0.0001$ & $473 \pm 51.73 \mathrm{ng} / \mathrm{ml}$ & $<0.0001$ \\
\hline DC & $99.44 \pm 27.58$ & & $732.62 \pm$ & \\
& $\mathrm{ng} / \mathrm{ml}$ & & $256.51 \mathrm{ng} / \mathrm{ml}$ & \\
\hline MNPDR & $167.36 \pm 42 . \mathrm{ng} / \mathrm{ml}$ & $<0.0001$ & $611.11 \pm$ & \\
& & & $60.26 \mathrm{ng} / \mathrm{ml}$ & $<0.0001$ \\
\hline SNPDR & $188.13 \pm$ & 0.01 & $902.25 \pm$ & $<0.0001$ \\
& $44.29 . \mathrm{ng} / \mathrm{ml}$ & & $114.28 \mathrm{ng} / \mathrm{ml}$ & \\
\hline PDR & $198.85 \pm 48.47$ & 0.03 & $1265.4 \pm$ & $<0.0001$ \\
& $\mathrm{ng} / \mathrm{ml} . \mathrm{ng} / \mathrm{ml}$ & & $156.04 \mathrm{ng} / \mathrm{ml}$ & \\
\hline
\end{tabular}

